\title{
Is living near a coking works harmful to health? A study of industrial air pollution
}

\author{
Rajinder S Bhopal, Peter Phillimore, Suzanne Moffatt, Christopher Foy
}

\begin{abstract}
Objective - To determine whether there was excess ill health in people living near a coking works, and if so whether it was related to exposure to coking works' emissions.

Design - Populations varying in proximity to the coking works were compared with control populations. Health data were correlated with available environmental data.

Methods - Analysis of routinely collected mortality, cancer registration, and birth statistics; community survey using self completed postal questionnaires; retrospective analysis of general practice (GP) records; tests of respiratory function; and analysis of available environmental data.
\end{abstract}

Main results - Study and control populations were comparable in terms of response rates, gender, and most socioeconomic indicators. For adults, age standardised mortality and cancer rates of the population closest to the coking works were comparable with those for the district as a whole. Gender ratios, birthweight, and stillbirth rates were comparable in the study and control populations. For several indicators of respiratory health including cough, sinus trouble, glue ear, and wheeze (but not for asthma and chronic bronchitis) there was a gradient of self reported ill health, with the highest prevalence in areas closest to the works. For example, sinus trouble was reported by $20 \%$ of adults and $13 \%$ of children in the area closest to the works compared with $13 \%$ and $6 \%$ respectively in the control area. GP consultations for respiratory disorders increased when pollution (measured by $\mathrm{SO}_{2}$ levels) was high: annual consultation rates per 1000 varied from 752 in the top group of daily pollution levels to 424 in the bottom group. Analysis of locally collected smoke and $\mathrm{SO}_{2}$ data indicated that $\mathrm{SO}_{2}$ concentrations were highest closest to the works and, after closure of the coking works, the number of days on which $\mathrm{SO}_{2}$ and smoke levels exceeded $100 \mu \mathrm{g} / \mathrm{m}^{3}$ and $90 \mu \mathrm{g} / \mathrm{m}^{3}$, respectively, fell steeply.

Conclusion - Routinely available indicators failed to provide convincing evidence that the coking works had harmed health. Self report and GP consultations indicated that respiratory ill health in the people living close to the works was worse than expected. Some of the excess probably resulted from exposure to cok- ing works emissions. The health effects of relatively low level but intermittently high air pollution from a point source may be subtle, contributing to respiratory morbidity, but not apparent in analysis of routine health indicators.

\section{( $\mathcal{F}$ Epidemiol Community Health 1994;48:237-247)}

In producing coke from coal, coking works release mixtures of air pollutants so complex that they remain incompletely characterised. ${ }^{1}$ Coke oven gases are extremely toxic and include carcinogens. Coke production is also associated with environmental disturbance in the form of noise, smell, and dirt. People who live close to coking works have shown understandable concern about both the potential danger to their health of exposure to the air pollution, and the inconvenience of living close to dirty industry. ${ }^{2}$

Studies of coke oven workers in several countries have consistently shown their higher than expected risk of lung cancer, ${ }^{3-5}$ a risk which is generally acknowledged to be causally related to exposure to coke oven gases and fumes. The few studies which have examined the health of people living close to coking works, however, have failed to answer the question, "Is living near a coke works a health risk?" Studies around the steel coke ovens in Sydney, Nova Scotia, suggested that mortality among men in the area was higher than in the province. ${ }^{2}$ German studies on the fluorine, ${ }^{6}$ arsenic, ${ }^{7}$ and phenol $^{8}$ concentrations in populations living near coking works have indicated a higher than expected phenol concentration in blood and urine, and by inference, benzene exposure.

The scientific evidence available to the local and health authorities in 1988 was insufficient to resolve a long standing and increasingly acrimonious dispute between residents living near Monkton Coking Works in the South Tyneside health district in the north east of England, the management of the coking works, and the local authority on the health hazards of coke works. Indeed, the controversy was such that the health concerns were central issues in a public inquiry, and received extensive media coverage. Our study was requested by the local authority, to help resolve this controversy.

\section{Setting}

The coking works was built with 33 ovens in 1937 in a "green field" site. Between the late 1940 s and 1960 s, housing estates (largely local authority owned) were built north, east, and south east of the site. The capacity of the works over the 53 years of production varied between 33 and 66 ovens. From 1980, 66 ovens were in operation. 
The coke ovens were in continuous operation except from April 1984 to January 1986, when closure followed a national miners' strike. Production finally ceased at short notice in October 1990.

Local residents' complaints concerned dirt, noise, unpleasant odours, and fumes, and ill health including chest diseases such as bronchitis, cancer, and early death. The areas concerned have, for residents, been smokeless zones since 1968 .

\section{Methods}

STUDY DESIGN, HYPOTHESES, DATA SOURCES, AND ETHICAL APPROVAL

Detailed health data and limited environmental data were collected on study and control populations matched on 1981 census data. The population of greatest interest was that living near the coking works. For each data set we defined an area close to the coking works, and a second area surrounding that. The health of the populations in these areas was compared with that in an area some $6-10 \mathrm{~km}$ distant from the coke works (control area), and in addition, for routinely collected health statistics only, with the whole of the health district.

The size, population, geographical relation to the coking works, and the terminology for the areas is given in table 1. The boundaries of areas under study were defined either on the basis of distance from and perceptions about exposure to coking works emissions, or using a computer model of emissions of $\mathrm{SO}_{2}$ from the coking works.

Figures 1 and 2 show, for example, the location of the coking works, the two sets of boundaries used for the analyses of the mortality and cancer data, the control area, and standardised mortality ratios for "all causes" and for lung cancer by housing estate (see results).

The four prior hypotheses which guided the analysis and interpretation of the data were that the health effects, if any, of emissions from the coking works would be:

(1) Greatest for respiratory conditions;

(2) Most marked for people living closest to the works;

(3) For acute conditions, diminished when the works was not in production or pollution levels were low;
(4) For acute conditions, most clearly seen in children.

The source, validity, and analysis of these data are described below. The South Tyneside Medical Research Ethics Committee approved the research.

\section{HEALTH DATA}

\section{Mortality, cancer registration}

Postcoded mortality data for 1981-89, and postcoded cancer registration data for 198689 , were obtained. Counts of cases were aggregated by housing estate and then by the areas shown in table 1 .

The 1981 census and projections for 1987 from the organisation CACI gave populations at enumeration district level. We estimated the 1984 population by taking the mid-point of the figures for 1981 and 1987.

Age and sex standardised rates and ratios were calculated with direct and indirect methods of standardisation, respectively, using the populations for 1981, 1984, and 1987. Because the results were influenced little by the method or the denominator, we subsequently used the indirect method yielding standardised mortality/morbidity ratios, with the 1984 (for 1981-89 mortality data) and 1987 denominators (for 1986-89 cancer morbidity data). The probability ( $p$ value) of the observed number of cases occurring in an area was calculated using the Poisson distribution. The $\mathrm{p}$ value for each cause was adjusted for multiple comparisons using the formula: adjusted $p=1-(1-p)^{m}$ where $m$ is the number of areas compared. These analyses used a computer program called GENRATE. ${ }^{9}$

\section{Birth data}

Postcoded birth data for 1982-89 were examined for the ratio of male to female births, birthweights, and stillbirths in the areas compared.

\section{Postal survey}

A systematic sample of the population in the areas described in table 1 , part $\mathrm{B}$, was drawn from the family health services authority register. The sample size was calculated to allow a difference of $5 \%$ between two proportions, $15 \%$ versus $20 \%$, to be detected with $80 \%$ power, at the $5 \%$ level of statistical signific-

Table 1 Size, population, and distance from the coking works

\begin{tabular}{|c|c|c|c|c|c|c|}
\hline \multicolumn{3}{|c|}{ Data source and study areas } & $\begin{array}{l}\text { No of } \\
\text { enumeration } \\
\text { districts }\end{array}$ & $\begin{array}{l}\text { Total } \\
\text { population } \\
\text { (1981 census) }\end{array}$ & $\begin{array}{l}\text { Nearest } \\
\text { distance } \\
\text { to coking } \\
\text { works }\end{array}$ & $\begin{array}{l}\text { Furthest } \\
\text { distance } \\
\text { from coking } \\
\text { works }\end{array}$ \\
\hline (A) & $\begin{array}{l}\text { Mortc } \\
\text { (i) } \\
\text { (ii) } \\
\text { (iii) } \\
\text { (iv) }\end{array}$ & $\begin{array}{l}\text { ity, cancer, and birth statistics: } \\
\text { Perceived exposure areas } \\
\text { Perceived highert } \\
\text { Perceived lower } \\
\text { Modelled area } \\
\text { Modelled higher } \\
\text { Modelled lower } \\
\text { Control area* } \\
\text { Whole of South Tyneside* }\end{array}$ & $\begin{array}{r}78 \\
42 \\
36 \\
67 \\
29 \\
38 \\
37 \\
349\end{array}$ & $\begin{array}{r}39451 \\
23092 \\
16359 \\
32761 \\
13367 \\
19394 \\
20929 \\
158972\end{array}$ & $\begin{array}{l}0.25 \mathrm{~km} \\
0.25 \mathrm{~km} \\
1.5 \mathrm{~km} \\
0.25 \mathrm{~km} \\
0.25 \mathrm{~km} \\
1.00 \mathrm{~km} \\
6.00 \mathrm{~km}\end{array}$ & $\begin{array}{r}4.5 \mathrm{~km} \\
3.0 \mathrm{~km} \\
4.5 \mathrm{~km} \\
3.5 \mathrm{~km} \\
2.0 \mathrm{~km} \\
3.5 \mathrm{~km} \\
10.0 \mathrm{~km}\end{array}$ \\
\hline (B) & $\begin{array}{r}\text { Comn } \\
\text { Inn } \\
\text { Ou }\end{array}$ & $\begin{array}{l}\text { inity, } G P \text {, and lung function surveys: } \\
\text { area } \\
\text { er area }\end{array}$ & $\begin{array}{l}28 \\
12 \\
16\end{array}$ & $\begin{array}{l}21364 \\
10581 \\
10783\end{array}$ & $\begin{array}{l}0.25 \mathrm{~km} \\
0.25 \mathrm{~km} \\
1.75 \mathrm{~km}\end{array}$ & $\begin{array}{l}2.5 \mathrm{~km} \\
1.75 \mathrm{~km} \\
2.5 \mathrm{~km}\end{array}$ \\
\hline
\end{tabular}

* Fixed for all comparisons.

"Fixed for all comparisons. staff, and general knowledge about aerosol dispersion patterns and wind direction. 

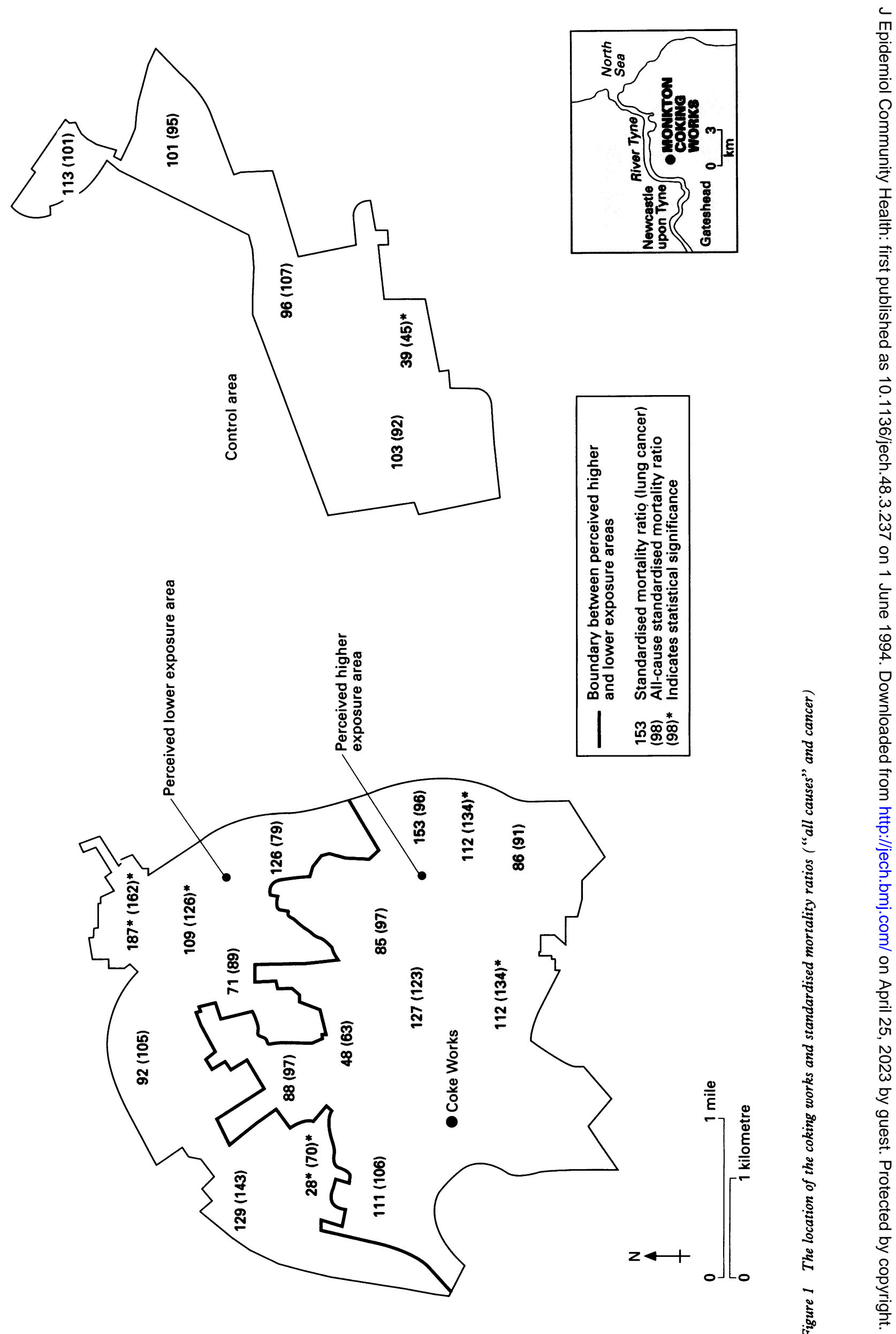


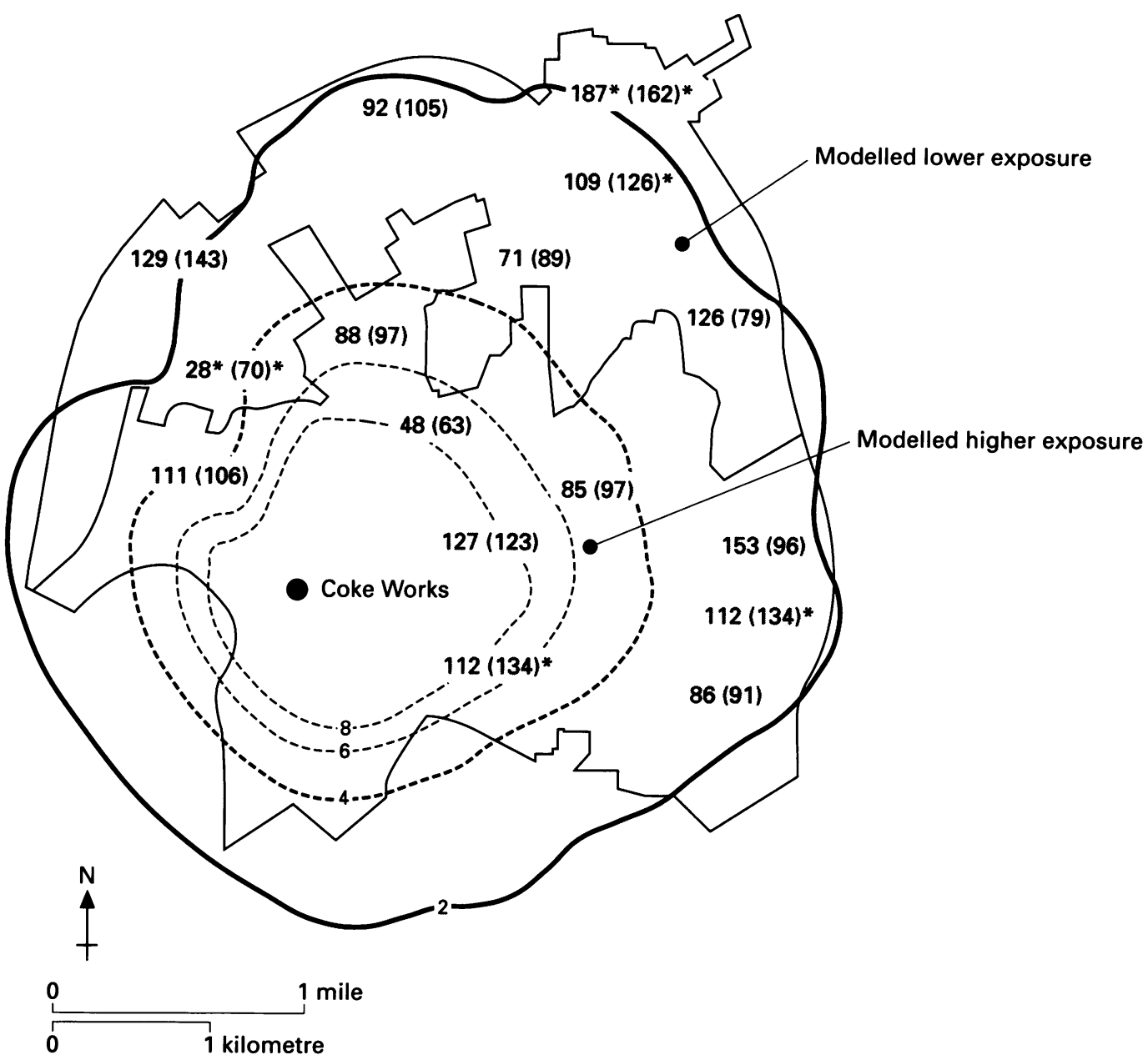

ance. Of the 4601 questionnaires sent out, 258 were returned as wrongly addressed, while $69.4 \%$ of the remainder were returned $(67.8 \%$ of questionnaires to adults, and $75 \cdot 1 \%$ of questionnaires to children) after two postal reminders to all the sample and use of telephone reminders. The response rates were similar for adults and children in all three areas - for example, for adults $69.6 \%$ in the inner, $65.3 \%$ in the outer, and $69.0 \%$ in the control area.

The questions concerned demographic details, health status, socioeconomic circumstances, individual behaviour, and perceptions of the factors that affect health.

The Medical Research Council's respiratory symptoms questionnaire was incorporated. ${ }^{10}$ Parents completed the questionnaire for children.
Comparisons between inner, outer, and control areas used the $\chi^{2}$ statistic for trend test.

The survey took place between November 1990 and February 1991.

\section{GENERAL PRACTICE MORBIDITY DATA}

Four general practices were selected, two located in the inner area which served both inner and outer area residents, and two in the control area. The case notes of all those patients registered with three practices and a systematic sample of one in four from the (largest) fourth practice, all of whom had also been sampled for the community survey, were examined ( 231 individuals lived in the inner area, 136 in the outer area, and 254 lived in the control area). Data on consultations, chronic conditions, hospital admissions, and current drug treatment were extracted from the medi- 
cal record and entered onto the AAH Medical Computer System which assigned the Read codes. Consultation data for the 56 months when smoke and $\mathrm{SO}_{2}$ levels were available were used. Details about the environmental data are given later. Analysis was by $\log$-linear modelling of the daily number of respiratory and non-respiratory consultations in each of the areas. Day of the week, mean daily temperature, and $\mathrm{SO}_{2}$ and smoke levels (mean of three sites) were used as explanatory variables. The GLIM statistical package was used.

\section{LUNG FUNCTION}

A sample of 142 children aged 8-14 years and 354 adults was drawn from the local family health services authority register. The sample was drawn from the inner and outer areas defined for the community postal survey. People were invited to a local health centre over a six day period ( $9 \mathrm{am}$ to $9 \mathrm{pm}$ ) in the week that the coking works closed. In addition, children who had not attended were visited in schools. The response rate for adults was $44 \%$, and that for children $78 \%$. For this reason only data on children are reported.

A brief questionnaire was used to collect demographic details and past medical history. Vitalograph spirometers were used to measure forced expiratory volume $\left(\mathrm{FEV}_{1}\right)$ and forced vital capacity (FVC), and a Wright peak flow meter for peak expiratory flow rate (PEFR). Height (using a Harpenden Stadiometer) and weight (using calibrated Avery Scales) were measured. The expected value for lung function was derived from formulae provided by Cotes. ${ }^{11}$

\section{ENVIRONMENTAL DATA}

At three local authority sites $(1 \mathrm{~km}$ north east, $1.5 \mathrm{~km}$ south east, and $0.75 \mathrm{~km}$ west of the coking works) 24 hour mean daily measures of $\mathrm{SO}_{2}$ and smoke had been made by the local authority over 56 months (1987-91) specifically to address concerns about the coking works. These data were used, in conjunction with meteorological data obtained from the

Table 2 Gender and age characteristics of the community survey

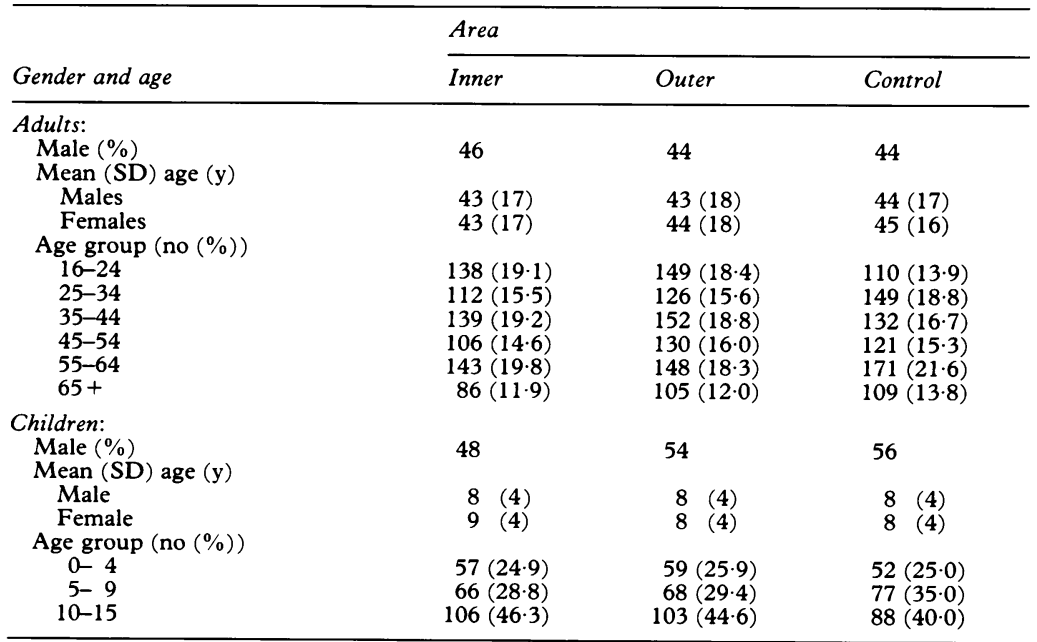

There are no significant differences in the sex ratio or age distribution between areas, for either adults or children.
Newcastle Weather Centre, to distinguish daily variations in atmospheric pollution and weather conditions. As the nearest housing is 250 metres from the coking works these monitoring sites did not provide an absolute level of exposure of the population. No routine data on air pollution were available for the control area. The nearest monitoring station was sited at a busy intersection near the town centre of South Shields (about one mile from the nearest boundary of the control area), and we obtained $\mathrm{SO}_{2}$ and smoke data from there, mainly to compare the pattern of change over time in these air pollutants.

\section{MODELLING}

Based on information provided by Her Majesty's Inspectorate of Pollution on the emissions from stacks at the coking works in 1989 (with the permission of Coal Products Limited), published data on low level emissions, ${ }^{12}$ and weather data, a model of the dispersion of emissions was prepared on our behalf by National Power using the Industrial Source Complex model of the Environmental Protection Agency (USA).

\section{Results}

\section{SOCIOECONOMIC FACTORS}

The social and economic circumstances of the populations in the inner, outer, and control areas, and in the whole of South Tyneside were similar, as shown by data from the 1981 census and by the postal survey (tables 2 and 3 show some of the data).

\section{MORTALITY AND CANCER REGISTRATION}

Tables 4 and 5 show that the adult "all cause" and cause specific standardised ratios for mortality and cancer registration in the higher exposure areas (whether perceived or modelled) closest to the coking works were not significantly different from those of South Tyneside as a whole, and were generally lower than those in the surrounding, lower exposure areas. For men in the areas closest to the coking works, SMRs were comparable with the control area. Women in the control area had lower ratios than their counterparts living near the coking works and in South Tyneside as a whole, an observation which remains unexplained.

Table 4 shows that children in the perceived higher exposure area had a $43.3 \%$ excess in mortality, and that in the modelled higher exposure area the excess was $75.2 \%$ (a statistically significant difference). The causes of death were, however, diverse and only one death was from cancer and one from respiratory disease.

\section{BIRTH DATA}

The male:female birth ratios in the perceived higher (1969 births), perceived lower (2066 births), and control (1713 births) areas were close to unity $(1.04,0.97$, and 1.00 respectively). In addition, the proportions of babies with birthweights less than $2500 \mathrm{~g}$ were comparable in the three areas $(8.0 \%, 6.3 \%$ and $7 \cdot 5 \%$ respectively). 
Table 3 Some social characteristics of the populations under study from the 1981 census and community survey

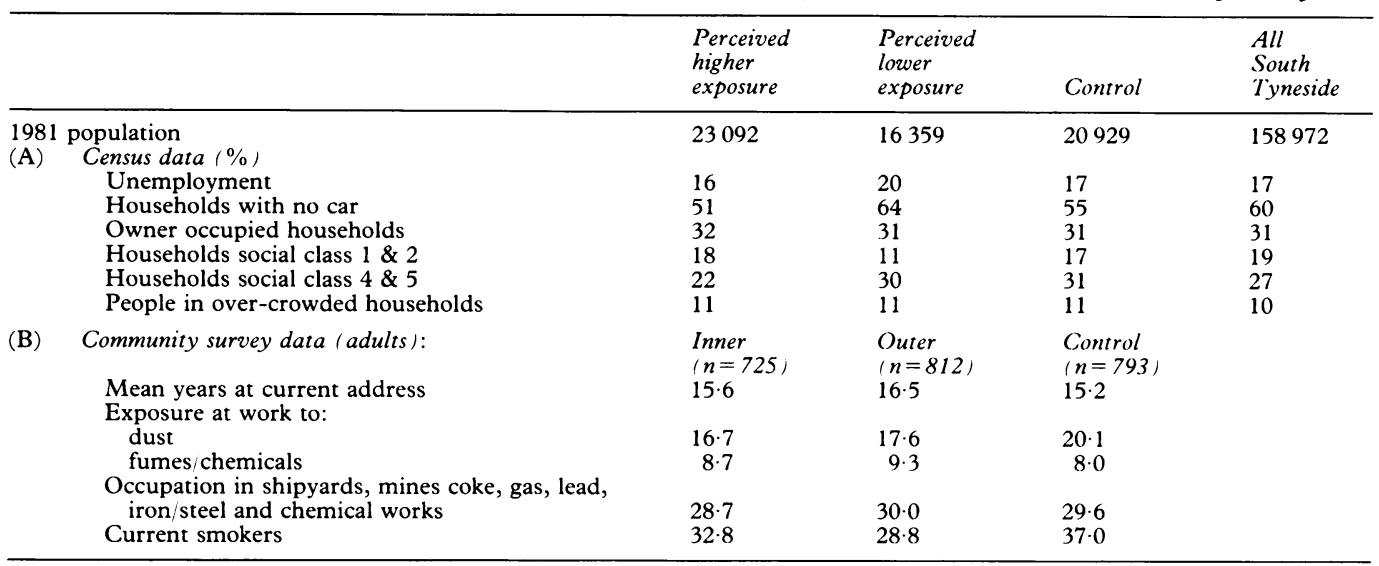

Table 4 Standardised mortality ratios* (numbers of deaths) by area, selected causes, and population subgroup; indicating statistical significance $\dagger^{\dagger}$

\begin{tabular}{|c|c|c|c|c|c|c|}
\hline & & Control & $\begin{array}{l}\text { Perceived } \\
\text { higher }\end{array}$ & $\begin{array}{l}\text { Perceived } \\
\text { lower }\end{array}$ & $\begin{array}{l}\text { Modelled } \\
\text { higher }\end{array}$ & $\begin{array}{l}\text { Modelled } \\
\text { lower }\end{array}$ \\
\hline (A) & $\begin{array}{l}\text { All cause mortality: } \\
\text { Both sexes, all ages } \\
\text { Males, all ages } \\
\text { Females, all ages } \\
0-14 \text { years, both sexes } \\
\text { 15-64 years, both sexes } \\
65+\text { years, both sexes }\end{array}$ & $\begin{array}{cc}95 & (2110) \\
102 & (1201) \\
88+ & (909) \\
119 & (28) \\
100 & (622) \\
93+(1460)\end{array}$ & $\begin{array}{r}100(2269) \\
97(1184) \\
104(1085) \\
143(41) \\
97(612) \\
101(1616)\end{array}$ & $\begin{array}{l}109(1934) \\
110+(973) \\
108+(961) \\
82(19) \\
120+(500) \\
106(1415)\end{array}$ & $\begin{array}{r}100(1407) \\
98(745) \\
103(662) \\
175 \dagger(24) \\
95(371) \\
101(1007)\end{array}$ & $\begin{array}{l}107+(2166) \\
105(1091) \\
110+(1075) \\
92(24) \\
113+(577) \\
106(1565)\end{array}$ \\
\hline (B) & $\begin{array}{l}\text { Cause specific mortality (ICD code): } \\
\text { Lung cancer, both sexes (162) } \\
\text { Lung cancer, males }(162) \\
\text { Lung cancer, females }(162) \\
\text { All other neoplasms except lung } \\
(141-161,163-239) \\
\text { Respiratory system }(450-519) \\
\text { Circulatory disease }(390-459)\end{array}$ & $\begin{array}{l}102(213) \\
102(156) \\
101 \quad(57) \\
\\
88+(362) \\
97(247) \\
97(1008)\end{array}$ & $\begin{array}{rr}108 & (225) \\
103 & (158) \\
122 & (67) \\
& \\
100 & (413) \\
104 & (274) \\
99 & (1040)\end{array}$ & $\begin{array}{rr}99 & (152) \\
95 & (104) \\
110 & (48) \\
& \\
118+(373) \\
100(212) \\
107 & (893)\end{array}$ & $\begin{array}{r}99(130) \\
91(88) \\
123(42) \\
107(274) \\
108(177) \\
98(639)\end{array}$ & $\begin{array}{rr}108 & (193) \\
105 & (136) \\
116 & (57) \\
& \\
110 & (400) \\
94 & (222) \\
108 & (1017)\end{array}$ \\
\hline
\end{tabular}

* The SMR is based on the mortality rates for South Tyneside District Health Authority

$+\mathrm{p}<0.05$ after adjustment for multiple comparisons.

POSTAL QUESTIONNAIRE SURVEY

The gender and age distributions of the samples in the three areas were matched, as shown in table 3. In answer to the open question, "Do you have any long-standing illness, disability, or infirmity?" there were no statistically significant differences: in adults, $28.6 \%$ in the inner area, $26.9 \%$ in the outer, and $25.4 \%$ in the control answered "yes", and in children the figures were $16.4 \%, 16.2 \%$, and $13.9 \%$.

Eight respiratory and 15 non-respiratory disorders were listed and adult respondents were asked whether they had ever had any of them. For children the list was of eight respiratory and five non-respiratory disorders. The prevalence data for all respiratory disorders, and for non-respiratory disorders where differences were statistically significant, are shown in table 6(A). Notably, there was no difference between areas in asthma and bronchitis prevalences. Table $6(\mathrm{~B})$ gives responses to the questions from the Medical Research Council's respiratory health questionnaire. Table 6 shows that for some, but not all, respiratory problems there were substantial differences between the inner, outer, and control areas, usually with a gradient with the highest prevalence in the inner area and the lowest in the control.

\section{GENERAL PRACTICE MORBIDITY DATA}

The comparison populations were comparable in gender and age. Forty eight per cent of the sample were male in the inner area compared with $52 \%$ in the outer area and $50 \%$ in the control area. The mean (SD) age of the subjects was $32.5(23.7)$ years in the inner area compared with $37.0(24.8)$ in the outer and $34.9(21.9)$ in the control areas. Sex and age did not differ significantly between areas.

Table 7 shows that for each air pollution level (measured by $\mathrm{SO}_{2}$ ) annual GP consultation rates for respiratory disorders were higher in the inner and outer areas than in the control area, whereas non-respiratory disease consultation rates were lower. The table also shows an association between the daily consultation rate for respiratory conditions and $\mathrm{SO}_{2}$ levels on the same day in the inner and outer areas. The association was not seen in the control area and was independent of daily temperature.

This association between daily $\mathrm{SO}_{2}$ levels and respiratory consultation rates was not observed when data were aggregated over longer periods - for example, comparing 198690 with 1984-86, when the coking works was not in production because of the national miners' strike. 
Table 5 Standardised cancer registration ratios* 1986-89 (number of cases) by area, selected causes and population subgroup; indicating statistical significance ${ }^{\dagger}$

\begin{tabular}{|c|c|c|c|c|c|c|}
\hline & & Control & $\begin{array}{l}\text { Perceived } \\
\text { higher }\end{array}$ & $\begin{array}{l}\text { Perceived } \\
\text { lower }\end{array}$ & $\begin{array}{l}\text { Modelled } \\
\text { higher }\end{array}$ & $\begin{array}{l}\text { Modelled } \\
\text { lower }\end{array}$ \\
\hline (A) & $\begin{array}{l}\text { All malignant neoplasms (ICD } 140-208 \text { ): } \\
\text { Both sexes } \\
\text { Males } \\
\text { Females } \\
0-14 \text { years } \\
15-64 \text { years } \\
65+\text { years }\end{array}$ & $\begin{array}{r}92(302) \\
98(167) \\
85(135) \\
0 \quad(0) \\
90(124) \\
94(178)\end{array}$ & $\begin{array}{l}104(360) \\
107(195) \\
101(165) \\
173(3) \\
101(146) \\
106(211)\end{array}$ & $\begin{array}{r}112(276) \\
111(138) \\
112(138) \\
73(1) \\
111(108) \\
113(167)\end{array}$ & $\begin{array}{r}110(233) \\
113(128) \\
106(105) \\
97(1) \\
112(100) \\
108(132)\end{array}$ & $\begin{array}{l}110(324) \\
108(162) \\
112(162) \\
196(3) \\
108(129) \\
110(192)\end{array}$ \\
\hline (B) & $\begin{array}{l}\text { Cause specific malignant neoplasms / ICD } \\
\text { Lung cancer, both sexes (162) } \\
\text { Lung cancer, male (162) } \\
\text { Lung cancer, female (162) } \\
\text { All other neoplasms except lung } \\
\text { (140-161, 163-208) } \\
\text { Genito-urinary (179-189) } \\
\text { Digestive }(150-159) \\
\text { Lymphatic haematological (200-208) } \\
\text { Lip, oral cavity, pharynx (140-149) } \\
\text { Skin (172-173) } \\
\text { Other and unspecified sites } \\
\text { (190-199) }\end{array}$ & $\begin{array}{rr}\text { de }): & \\
81 & (65) \\
83 & (47) \\
76 & (18) \\
& \\
95 & (237) \\
87 & (47) \\
100 & (76) \\
114 & (13) \\
122 & (7) \\
119 & (37) \\
69 & (19)\end{array}$ & $\begin{array}{rr}108 & (90) \\
112 & (67) \\
98 & (23) \\
& \\
103 & (270) \\
89 & (51) \\
108 & (85) \\
107 & (13) \\
166 & (10) \\
111 & (36) \\
108 & (31)\end{array}$ & $\begin{array}{rr}126 & (74) \\
105 & (43) \\
174 \dagger(31) \\
107 \\
107(202) \\
123(50) \\
108(62) \\
58(5) \\
94 \quad(4) \\
117(28) \\
130(31)\end{array}$ & $\begin{array}{rr}89 & (46) \\
93 & (35) \\
76 & (11) \\
& \\
167 & (187) \\
97 & (34) \\
119 & (58) \\
95 & (7) \\
188 & (7) \\
110 & (22) \\
145 & (26)\end{array}$ & $\begin{array}{l}130 \dagger(91) \\
120(59) \\
154+(32) \\
104(233) \\
115(56) \\
110(75) \\
106(11) \\
116(6) \\
106(30) \\
105(26)\end{array}$ \\
\hline
\end{tabular}

* The SMR is based on the cancer rates for South Tyneside District Health Authority.

$+\mathrm{p}<0.05$ after adjustment for multiple comparisons.

Table 6 (A) Postal survey: Self reported past or present ill health in adults and children by area and (B) Medical Research Council Respiratory Symptoms Questionnaire

\begin{tabular}{|c|c|c|c|c|c|c|c|c|}
\hline & \multicolumn{4}{|l|}{ Adults } & \multicolumn{4}{|l|}{ Children } \\
\hline & $\begin{array}{l}\text { Inner } \\
(n=725) \\
(\%)\end{array}$ & $\begin{array}{l}\text { Outer } \\
\left(\begin{array}{l}n=812) \\
(\%)\end{array}\right.\end{array}$ & $\begin{array}{l}\text { Control } \\
\left(\begin{array}{l}n=793) \\
(\%)\end{array}\right.\end{array}$ & $\chi^{2}$ trend & $\begin{array}{l}\text { Inner } \\
(n=231) \\
(\%)\end{array}$ & $\begin{array}{l}\text { Outer } \\
(n=233) \\
(\%)\end{array}$ & $\begin{array}{l}\text { Control } \\
(n=221) \\
\%\end{array}$ & $\chi^{2}$ trend \\
\hline \multicolumn{9}{|l|}{ (A) Postal survey: } \\
\hline \multicolumn{9}{|l|}{ Respiratory problems: } \\
\hline Asthma & $5 \cdot 9$ & $6 \cdot 7$ & $5 \cdot 3$ & NS & $11 \cdot 3$ & $10 \cdot 3$ & $11 \cdot 3$ & NS \\
\hline Bronchitis & - & - & - & & $10 \cdot 4$ & $7 \cdot 3$ & $9 \cdot 5$ & NS \\
\hline Chronic bronchitis & $8 \cdot 1$ & $8 \cdot 0$ & $7 \cdot 4$ & NS & - & - & - & \\
\hline Hay Fever & $12 \cdot 3$ & $11 \cdot 1$ & $8 \cdot 4$ & $5.97 \mathrm{p}<0.02$ & $10 \cdot 8$ & $11 \cdot 6$ & 5.9 & $4.32 \mathrm{p}<0.05$ \\
\hline Other chest trouble & 10.9 & $11 \cdot 1$ & $8 \cdot 8$ & NS & $13 \cdot 0$ & $11 \cdot 2$ & $4 \cdot 2$ & $12.40 \mathrm{p}<0.001$ \\
\hline Pneumonia & $5 \cdot 2$ & $6 \cdot 3$ & $5 \cdot 0$ & NS & 0.9 & 0 & $2 \cdot 3$ & NS \\
\hline $\begin{array}{l}\text { Pleurisy } \\
\text { Pla }\end{array}$ & $5 \cdot 7$ & $5 \cdot 4$ & $5 \cdot 2$ & NS & $1 \cdot 7$ & 0.9 & 0 & $4.25 p<0.05$ \\
\hline Sinus trouble & $20 \cdot 1$ & $17 \cdot 1$ & $13 \cdot 1$ & $13.50 \mathrm{p}<0.001$ & $13 \cdot 4$ & $6 \cdot 9$ & $5 \cdot 9$ & $9.85 \mathrm{p}<0.05$ \\
\hline Tuberculosis & $2 \cdot 8$ & $3 \cdot 2$ & $1 \cdot 6$ & NS & - & - & - & \\
\hline \multicolumn{9}{|l|}{ Non-respiratory problems: } \\
\hline $\begin{array}{l}\text { Allergies } \\
\text { Allos }\end{array}$ & $11 \cdot 4$ & $9 \cdot 2$ & $7 \cdot 2$ & $8.20 p<0.01$ & $14 \cdot 3$ & $8 \cdot 2$ & $7 \cdot 2$ & $8.01 \mathrm{p}<0.01$ \\
\hline Headache & 37.9 & $35 \cdot 0$ & 31.5 & $6.88 \mathrm{p}<0.01$ & $23 \cdot 4$ & $21 \cdot 0$ & $14 \cdot 0$ & $8.75 \mathrm{p}<0.01$ \\
\hline Itchy rash eczema & - & - & - & & 23.8 & $23 \cdot 6$ & 14.9 & $7.77 \mathrm{p}<0.01$ \\
\hline Skin rash trouble & $11 \cdot 0$ & $12 \cdot 9$ & $9 \cdot 1$ & NS & & & & \\
\hline \multicolumn{9}{|l|}{ (B) MRC Questionnaire } \\
\hline \multicolumn{9}{|l|}{ Chronic cough: } \\
\hline Grade $1^{*}$ & $7 \cdot 3$ & $4 \cdot 5$ & $3 \cdot 8$ & $9.48 \mathrm{p}<0.01$ & $4 \cdot 1$ & $5 \cdot 9$ & $3 \cdot 7$ & NS \\
\hline Grade $2 \dagger$ & $17 \cdot 0$ & 14.5 & $13 \cdot 9$ & $6.36 \mathrm{p}<0.02$ & 11.8 & $10 \cdot 0$ & $6 \cdot 0$ & $5.90 p<0.02$ \\
\hline Summer cough: & $28 \cdot 3$ & $24 \cdot 9$ & $18 \cdot 5$ & $20.00 \mathrm{p}<0.001$ & $12 \cdot 2$ & $13 \cdot 3$ & $6 \cdot 0$ & $6.06 \mathrm{p}<0.02$ \\
\hline \multicolumn{9}{|l|}{ Chronic phlegm: } \\
\hline All day & $19 \cdot 3$ & $16 \cdot 2$ & $13 \cdot 5$ & $9.39 p<0.01$ & $2 \cdot 3$ & $4 \cdot 2$ & $1 \cdot 0$ & NS \\
\hline Part day & 4.0 & 3.5 & $2 \cdot 4$ & NS & 14.7 & 13.0 & $9 \cdot 1$ & $4.77 p<0.05$ \\
\hline Summer phlegm & $26 \cdot 7$ & $22 \cdot 1$ & $17 \cdot 2$ & $20.49 p<0.01$ & $2 \cdot 3$ & 4.5 & $1 \cdot 2$ & NS \\
\hline Simple chronic bronchitis & $16 \cdot 3$ & $13 \cdot 4$ & $12 \cdot 4$ & $5.49 \mathrm{p}<0.05$ & & & & \\
\hline $\begin{array}{l}\text { Complicated }+ \text { chronic } \\
\text { bronchitis }\end{array}$ & $4 \cdot 7$ & $4 \cdot 3$ & $3 \cdot 3$ & NS & & & & \\
\hline Complicated $\S$ chronic & & & & & & & & \\
\hline bronchitis & 8.9 & $6 \cdot 2$ & $5 \cdot 4$ & $7.38 \mathrm{p}<0.01$ & & & & \\
\hline \multicolumn{9}{|l|}{ Breathlessness } \\
\hline Grade $1^{* *}$ & $5 \cdot 3$ & $5 \cdot 7$ & $3 \cdot 1$ & $3.87 \mathrm{p}<0.05$ & 1.4 & 1.9 & 1.0 & NS \\
\hline Grade $2+\dagger$ & $7 \cdot 6$ & $6 \cdot 3$ & $5 \cdot 8$ & NS & 1.4 & 0.9 & 1.5 & NS \\
\hline Wheeze in last 12 months & $31 \cdot 3$ & $28 \cdot 1$ & $25 \cdot 0$ & $7.55 \mathrm{p}<0.01$ & $23 \cdot 8$ & $22 \cdot 1$ & $11 \cdot 0$ & $49.78 p<0.001$ \\
\hline Reversible wheeze & $15 \cdot 3$ & 14.5 & $12 \cdot 9$ & NS & $10 \cdot 2$ & $10 \cdot 3$ & $6 \cdot 3$ & NS \\
\hline Short of breath at night & 12.7 & $11 \cdot 7$ & $10 \cdot 1$ & NS & $7 \cdot 7$ & $7 \cdot 2$ & 3.8 & $4.24 \mathrm{p}<0.05$ \\
\hline
\end{tabular}

Comparisons are by $\chi^{2}$ for trend.

* Grade $1=$ Usually cough first thing in the morning in winter or during the day or night and on most days for three months per year.

+ Grade $2=$ Cough first thing in the morning in winter and during the day or night and on most days for three months per year.

+ Increased cough and phlegm for 3 months per year and more than one serious chest illness in past 3 years.

$\$$ Increased cough and phlegm for 3 months per year and within the past three years, a period of cough or phlegm lasting 3 weeks or more.

** Grade $1=$ Short of breath on walking and short of breath on hills.

++ Grade $2=$ As above and have to stop for breath on walking.

LUNG FUNCTION

Table 8 shows that the FEV, FVC, and PEFR of both boys and girls in the inner and outer areas were close to those predicted.

OBSERVATIONS ON ENVIRONMENTAL POLLUTION Levels of $\mathrm{SO}_{2}$ and smoke

Table 9 shows that $\mathrm{SO}_{2}$ levels measured around the coking works (three gauges) were higher than in South Shields in the OctoberMarch period before the closure of the coking works but lower in the same period after its closure. Smoke levels did not alter significantly around the coking works but rose in South Shields. $\mathrm{SO}_{2}$ levels rarely exceeded established EC guidelines $\left(100-150 \mu \mathrm{g}\right.$ of $\mathrm{SO}_{2}$; 
Table 7 Relation of air pollution level and annual general practice consultations per 1000 population

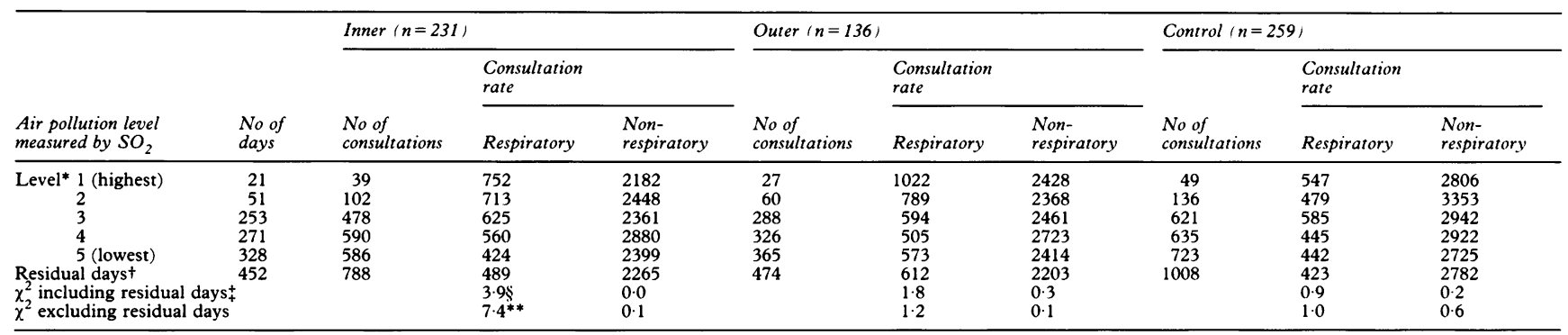

*Actual air pollution levels are as follows: $1, \mathrm{SO}_{2}>100 \mu \mathrm{g} / \mathrm{m}^{3}$ at two or more monitoring sites; $2, \mathrm{SO}_{2}>100 \mu \mathrm{g} / \mathrm{m}^{3}$ at one monitoring site; $3,62 \mu \mathrm{g} / \mathrm{m}^{3}<\mathrm{SO}, \leqslant 100 \mu \mathrm{g} /$ $\mathrm{m}^{3} ; 4,41 \mu \mathrm{g} / \mathrm{m}^{3}<\mathrm{SO}_{2} \leqslant 62 \mu \mathrm{g} / \mathrm{m}^{3} ; 5, \mathrm{SO}_{2} \leqslant 41 \mu \mathrm{g} / \mathrm{m}^{3}$.

t Residual days are those which fall within four days of pollution categories $1-3$.

$+\chi^{2}$ values for the effect of the mean daily $\mathrm{SO}_{2}$ level on the daily number of consultations (controlling for temperature and day of week).

$\$ \mathrm{p}<0.05(1 \mathrm{df})$.

24 hour mean values). The days on which $\mathrm{SO}_{2}$ levels exceeded $100 \mu \mathrm{g} / \mathrm{m}^{3}$ were mainly in the months of October $(10.4 \%$ of total $)$, November $(24.6 \%)$, December $(21.7 \%)$, and January $(9 \cdot 5 \%)$, and were associated with anticyclonic weather, when pollutants tend to disperse around the source without strong directional preference. The number of such events in the period November 1987 to December 1989 was 109 (equivalent to 19 per 100 days) and in the running down period before closure of the coking works, January 1990-October 1990, it was seven (two per 100 days). After the coking works was closed in October 1990, there were no such events.

\section{Modelling of pollution dispersion}

The model is shown in figure 2 . The modelling confirmed that the highest concentrations of pollutants (as indicated by $\mathrm{SO}_{2}$ ), were close to the coking works, and that there was a rapid

Table 8 Actual and predicted ${ }^{*}$ mean values for lung function in children adjusted for age and height

\begin{tabular}{|c|c|c|c|c|c|c|}
\hline & \multicolumn{2}{|l|}{$F E V$} & \multicolumn{2}{|l|}{$F V C$} & \multicolumn{2}{|l|}{ PEFR } \\
\hline & Actual & Predicted & Actual & Predicted & Actual & Predicted \\
\hline $\begin{array}{l}\text { Males } \\
\text { All } \\
\text { Inner } \\
\text { Outer }\end{array}$ & $\begin{array}{l}2 \cdot 40 \\
2 \cdot 38 \\
2 \cdot 43\end{array}$ & $2 \cdot 32$ & $\begin{array}{l}2 \cdot 78 \\
2.74 \\
2 \cdot 84\end{array}$ & $2 \cdot 81$ & $\begin{array}{l}361 \\
370 \\
353\end{array}$ & 328 \\
\hline $\begin{array}{l}\text { Females } \\
\text { All } \\
\text { Inner } \\
\text { Outer }\end{array}$ & $\begin{array}{l}2.20 \\
2.37 \\
2.08\end{array}$ & $2 \cdot 13$ & $\begin{array}{l}2.55 \\
2.55 \\
2.55\end{array}$ & $2 \cdot 45$ & $\begin{array}{l}336 \\
350 \\
334\end{array}$ & 356 \\
\hline
\end{tabular}

* Predicted levels from Cotes"

$\mathrm{FEV}_{1}=$ forced expiratory volume in one second; $\mathrm{FVC}=$ forced vital capacity; $\mathrm{PEFR}=$ peak expiratory flow rate. decline in concentrations with distance. The maximal annual average $\mathrm{SO}_{2}$ ground level concentration due to sources from the works was estimated to be $40 \mu \mathrm{g} / \mathrm{m}^{3}$ at a position 200 metres east of the works.

\section{Discussion}

While seeking to avoid the mistaken attribution of causality to mere association, we were concerned not to overlook the health effects of community exposure to coking works emissions by using insufficiently sensitive methods. Accordingly, we went beyond the scope of most studies of the health of populations living near industry ${ }^{13}$ which have focussed on either routine data, ${ }^{1415}$ or community based surveys. ${ }^{1617} \mathrm{We}$ demonstrated an association between living close to a coking works and some aspects of respiratory ill health.

ARE THE FINDINGS EXPLAINED BY ARTEFACT? We paid close attention to the following common problems which may cause artefact:

(i) Multiple comparisons. In analysing routine mortality and cancer registration data we adjusted $\mathrm{p}$ values for multiple comparisons;

(ii) Inaccurate population data. We tested the robustness of our data using several estimates of the population, and by assessing whether disease excesses or deficits are specific or unspecific (the latter would be expected with an erroneous denominator);

(iii) Biased self reports on health. We asked about health matters which would be unrelated to the exposure of interest (for example, arthritis, stomach trouble, and haemorrhoids), and on a wide range of conditions which might potentially be associated to the exposure,

Table 9 Comparison of $\mathrm{SO}_{2}$ and smoke levels during October-March for the area around the coking works and South Shields

\begin{tabular}{|c|c|c|c|c|c|c|c|}
\hline & \multirow[b]{2}{*}{$\begin{array}{l}\text { No of } \\
\text { days }\end{array}$} & \multicolumn{3}{|c|}{ Mean $(S E M) \mathrm{SO}_{2}\left(\mathrm{ug} / \mathrm{m}^{3}\right)$} & \multicolumn{3}{|c|}{ Mean (SEM) smoke $\left(\mathrm{ug} / \mathrm{m}^{3}\right)$} \\
\hline & & $\begin{array}{l}\mathrm{SO}_{2} \text { in study } \\
\text { area (mean } \\
\text { of } 3 \text { gauges) }\end{array}$ & $\begin{array}{l}\mathrm{SO}_{2} \text { in } \\
\text { South } \\
\text { Shields }\end{array}$ & $\begin{array}{l}\text { Difference } \\
\text { (study area } \\
\text { less } S \text { Shields) }\end{array}$ & $\begin{array}{l}\text { Smoke in study } \\
\text { area (mean of } \\
3 \text { gauges) }\end{array}$ & $\begin{array}{l}\text { Smoke in } \\
\text { South } \\
\text { Shields }\end{array}$ & $\begin{array}{l}\text { Difference } \\
\text { (study area } \\
\text { less S Shields) }\end{array}$ \\
\hline \multirow{3}{*}{$\begin{array}{l}\text { October-March } \\
1989-90 \\
\text { October-March } \\
1990-91 \\
\text { Mann-Whitney } \\
\text { U test comparing } \\
\text { October-March periods }\end{array}$} & 170 & $45 \cdot 0(1 \cdot 1)$ & $41 \cdot 0(1 \cdot 1)$ & $4.0(0.8)$ & $18 \cdot 3(1 \cdot 2)$ & $18 \cdot 7(1 \cdot 2)$ & $-0.4(0.6)$ \\
\hline & 129 & $31.9(1.3)$ & $37 \cdot 4(1 \cdot 7)$ & $-5.5(1.2)$ & $19 \cdot 9(1.4)$ & $24 \cdot 0(1 \cdot 7)$ & $-4 \cdot 1(0 \cdot 8)$ \\
\hline & & $\mathrm{p}<0.0001$ & $\mathrm{p}=0.025$ & $\mathrm{p}<0.0001$ & $p=0.52$ & $\mathrm{p}=0.006$ & $\mathrm{p}<0.0001$ \\
\hline
\end{tabular}

Values are only for days when readings existed for both the study and South Shields sites.

The period of 1-17 October 1990 (immediately prior to the works' closure) is not included. 
hence assessing the specificity of the associations. We also asked about respiratory health in several ways in the community questionnaire, and studied it at several levels of morbidity;

(iv) Differences in use of or access to primary care services. We found that overall consultation rates were lower in the population living near the coking works;

(v) Confounding variables. We compared our populations with regard to a wide range of demographic, social, economic, occupational, lifestyle, and environmental circumstances, adjusting for age and sex where appropriate;

(vi) Lack of power. We used all the mortality, cancer, and birth data available with postcodes, and calculated sample sizes for the community survey to detect prevalence differences of $5 \%$.

We believe that artefact does not fully explain our observations.

\section{IS THE HEALTH OF PEOPLE LIVING NEAR THE COKING WORKS DIFFERENT FROM THAT IN COMPARABLE POPULATIONS?}

The mortality and cancer experience of men and women living closest to the coking works was similar to that of the South Tyneside population, and for men, to that of the control area. The women in the control area had significantly low rates compared with South Tyneside women and, therefore, women in areas closest to the coking works. We cannot explain this latter observation. Overall, for adults, there was no clear evidence that mortality and cancer rates were greater than expected in the populations most exposed to coking works' emissions.

Mortality in children in the area closest to the works was higher than in South Tyneside and the control area. The excess of mortality was distributed across a range of causes. On balance, we consider it unlikely that this excess was attributable to exposure to works' emissions but we are re-examining the question with new data. Children in the areas close to the coking works had birthweights, stillbirth rates, and gender ratios comparable with control and South Tyneside populations. The lung function of children in the inner and outer areas was as predicted on the basis of physiological norms. ${ }^{11}$ Lung function was tested as the coking works closed, and shortly afterwards, so chronic effects only could have been detected.

The community survey, and analysis of general practice consultations, showed that in many respects the populations closest to the coking works had a similar health experience to that in the control area. However, for a number of problems, mainly of the upper respiratory tract, there were large differences. Hay fever, glue ear, cough, and wheeze stood out as problems with a high prevalence on self report. Notably, both asthma and bronchitis prevalence was not higher on self report. If prevalence differences had been caused by reporting bias resulting from dwareness of the hypotheses, then a self reported excess of these two conditions would have been seen, for these were problems identified by the community as being associated with the works. The prevalence of chronic bronchitis on self report was no higher in the inner area, but when it was derived indirectly, based on a series of questions in the Medical Research Council Respiratory Questionnaire, there was a significant difference. The community survey and GP study corroborated each other in demonstrating differences in respiratory morbidity. The fact that most of the differences in children concerned the upper respiratory tract is compatible with the findings on the lung function of children.

\section{HAVE COKING WORKS EMISSIONS BEEN}

RESPONSIBLE FOR THE POORER HEALTH?

Ideally, new, standardised environmental measures of air pollution should have been made in the study and control areas. Unfortunately, the sudden and unexpected closure of the coking works forced us to rely on available data.

The $\mathrm{SO}_{2}$ and smoke data from three sites around the coking works do not reflect the actual levels to which the study populations were exposed; these would have been higher nearer the coking works. The data from the town centre, South Shields, are used solely to compare time trends in $\mathrm{SO}_{2}$ and smoke levels with data from around the coking works.

Study and control areas were chosen on the basis of their similar housing, street layout, and traffic levels. No other major industrial sources of air pollution existed close to the coking works or in the control area. On the basis of the data on stack and fugitive emissions from the coking works, the changing mean levels of $\mathrm{SO}_{2}$ in the air and the decline in the frequency of $\mathrm{SO}_{2}$ readings exceeding $100 \mu \mathrm{g}$ in relation to declining activity at the works, field observations, and published observations on the polluting nature of coking plants, ${ }^{1}$ we can assume that the plant was the largest single contributor to local air pollution. Two computer models and an analysis of $\mathrm{SO}_{2}$ levels in relation to weather conditions indicated that pollution levels would be highest closest to the works and diminish rapidly with distance. In this context we infer that health differences between the study and control areas were not caused by another external source of air pollution.

Three of our four prior hypotheses were upheld and the fourth partly upheld. The demonstrable health differences were, with the exception of childhood mortality, specific and mainly for selected respiratory problems; the gradients in prevalence of problems we predicted (inner $>$ outer $>$ control) were observed for most of the respiratory problems; and the greatest differentials in prevalence rates were in children. The hypothesis that respiratory health would improve during the periods of closure of the coking works, tested by comparisons of GP consultation rates over periods of several months' duration, was not upheld; however, we found that there was a clear relation between daily patterns of consultation for respiratory disorders and periods when 
daily air pollution was highest, as indicated by $\mathrm{SO}_{2}$, a pollutant specifically associated with activity at the coking works. The epidemiological criteria for causality were fulfilled as follows:

\section{Timing}

The exposure preceded the effect. The stability of the populations makes it implausible that populations susceptible to some, but not all, respiratory problems selectively migrated into the neighbourhood of the coking works.

Strength of the association and dose-response The associations were moderate in strength, and an exposure-effect gradient was seen both in the community survey data and the air pollution $\left(\mathrm{SO}_{2}\right)$ and GP consultations data.

\section{Specificity}

The effects agreed with prior predictions, and were most marked for upper respiratory problems. The fact that the excess was not seen in all respiratory problems, especially self reported chronic bronchitis and asthma, is particularly noteworthy as an argument against the possibility that the differences are simply a result of reporting bias. The main exception to the observation that differences were fairly specific was childhood mortality, which we are studying further.

\section{Consistency}

The methodological problems of measuring exposure to air pollution in a community setting make the collection of convincing evidence of cause and effect extremely difficult, and the evidence on the effect of industrial air pollution from point sources on human health is conflicting. The studies of Lloyd et $\mathrm{al}^{14}$ are unusual in demonstrating effects on mortality, cancer, and gender ratios of industrial air pollution from steel and foundry plants. Elliot $e t$ al found no excess laryngeal cancer around incinerators, ${ }^{15}$ and Symington et al no excess of respiratory symptoms near a foundry. ${ }^{16}$ Dales et al showed an association between living downwind of a gas refinery and self reported respiratory health but not with lung function, but were unable to exclude reporting bias as an explanation. ${ }^{17}$ The Harvard six cities study ${ }^{18} 19$ examined children's health at contemporary levels of air pollution and found a link between air pollution and several aspects of reported respiratory health, including earache ${ }^{19}$, but not lung function. ${ }^{1819}$ The asthma prevalence was not in excess in the most polluted cities. ${ }^{19}$ Viegi et al compared the self reported health of general populations, both exposed and unexposed to industrial air pollution, and showed a strong link between exposure and both upper and lower respiratory tract ill health. ${ }^{20} \mathrm{Kar}$ daun et al linked $\mathrm{SO}_{2}$ levels to GP consultation rates for respiratory disease in Amsterdam. ${ }^{21}$ Pope et al showed a link between fine particu- late pollution from a steel mill and hospital admissions for several respiratory diseases. ${ }^{22}$

The link between high levels of air pollution and mortality is clear, but the effect of low level air pollution is not. MacKenbach et al have shown that an apparent link between low levels of $\mathrm{SO}_{2}$ and mortality in The Netherlands was lost when the data were adjusted for the lagged effects of temperature. ${ }^{23}$

$\mathrm{SO}_{2}$ levels of the order measured here have not been shown to produce respiratory problems in experimental studies on human beings. ${ }^{24}$ These studies, however, concern high levels of $\mathrm{SO}_{2}$ over brief periods of time. We make no claim that $\mathrm{SO}_{2}$, alone, was the cause of respiratory ill health but that it resulted from the combination of pollutants from the coking works (for the changing levels of which $\mathrm{SO}_{2}$ levels provide an indirect measure). Other recent work, both published ${ }^{17-22}$ (reviewed recently ${ }^{24}$ ) and unpublished (Walters et al, paper presented to National Public Health Conference, West Midlands 1991; and Meduna $\mathrm{S}$ et al, "An epidemiological surveillance system for the management of air pollution episodes: the ERPUS project," paper presented to the Faculty of Public Health Medicine, 1992 Annual Scientific Meeting, Eastbourne) supports our finding that air pollution levels of the order reported here, which may be measured using $\mathrm{SO}_{2}$ and/or smoke as markers, are associated with morbidity.

Our data, linking relatively low levels of industrial air pollution to respiratory ill health (both self reported and as assessed by GP records) but not lung function tests or mortality, are consistent with contemporary epidemiological findings and add to the growing evidence that safe thresholds for air pollution have yet to be defined. ${ }^{13-24}$

\section{Plausibility}

It is plausible, as discussed in a recent review ${ }^{24}$ (chapter 5), that long term, low level (but intermittently high) exposure to a complex mixture of pollutants including $\mathrm{SO}_{2}$ would affect upper and lower respiratory tract health. This research emphasises that the upper respiratory tract may be affected by air pollution, an under-researched field in epidemiology. It is notable that in air pollution epidemiology the emphasis has been on inhalable particles, and that most measurement methods for particulates have not been designed to measure particles which are likely to impact on the upper respiratory tract (personal communication: Mark D, Hall D, Latest developments in ambient dust and aerosol monitoring. Unpublished paper, Warren Springs Laboratory).

\section{CONCLUSION}

The local community's observations that emissions from the coking works affected their health were probably correct. The excess of respiratory problems observed in those living close to the works can best be explained as a result of their exposure to its emissions. The 
observed excess in childhood mortality cannot, on our evidence, be attributed to such exposure but requires more research. This and other communities living close to coking works should be reassured by the finding that there was no major and discernible impact on adult mortality and cancer, birthweight and stillbirth, and lung function in children was as predicted.

This work provides support for the view that health effects of environmental pollution may be subtle and not always be discernible from mortality data, ${ }^{25}$ provides a framework for an investigation focussing on morbidity, and emphasises further the need for a close dialogue between policy makers, researchers, and communities concerned about environmental health issues. ${ }^{132627}$

We wish to thank South Tyneside Metropolitan Borough Council for funding the study and the following people for their help: Angus McNay, Simon Raybould, David Chinn, John Cotes, Peter Blain, John Edwards, Dennis Wheeler, Malcolm Newson, Tim Butler, Helen Groom, Ann Rooke, David Hall, Alistair Hay, Carolyn McGregor, Denise Howel, Fred Nimmo, Alistair Hay, Carolyn McGregor, Denise Howel, Fred Nimmo, FHSA, DHA and schools, HMIP, AAH Meditel and National Power.

1 Lave L, Leonard B. Regulating coke oven emissions. In: Paustenbach $\mathrm{D}$, ed. The risk assessment of environmental and human health hazards. New York: John Wiley, 1989.

2 Donham P. No smoke, no baloney. Canadian Centre for Occupational Health and Safety. At the Centre. 1986;9: $2-4$.

3 Lloyd JW. Long term mortality study of steelworkers V. Respiratory cancer in coke plant workers. $\mathcal{f}$ Occup Med 1971;13:53-68.

4 Redmond CK, Ciocco A, Lloyd WL, Rush HW. Longterm mortality study of steeelworkers VI. Mortality from malignant neoplasms among coke oven workers. $\mathcal{F}$ Occup Med;1972;14:621-9.

5 Hurley JF, Archibald RMcL, Collings PL, Fanning DM, Jacobson M, Steele RC. The mortality of coke oven workers in Britain. Am $\mathcal{F}$ Ind Med 1983;4:691-704.

6 Einbrodt HJ, Prajsner D, Kuhne HJ, Frank K. Flourine exposure of persons at coking plants and their vicinity. Wissenschaft und Umwelt 1978;3:172-4.

7 Eikmann T, Michels S, Walliser L, Krauth W, Einbrodt $H J$. The environmental burden of man by arsenic part $I$. Epidemiology of adult residents near to a coke works. Staub-Reinhalt Luft 1984;44:144-8.

8 Eikmann T, Muller W, Prajjner D. Phenol excretion and haematological values as parameters for a benzene burden. A comparative study of the adult population of two den. A comparative study of the adult population of two

provincial towns. Wissenschaft und Umwelt 1980;4:183-9.
9 Nimmo AW. Review of computer mapping of health data. Health Bull (Edin) 1989;47:40-54.
Himmo AW. Review of computer mapt

10 Committee on the aetiology of chronic bronchitis. Definition and classification of chronic bronchitis for clinical and epidemiological purposes. Lancet 1965;i:775-9.

11 Cotes J. Lung function assessment and application in medicine 4th ed. Oxford: Blackwell, 1979.

12 Gemmil RJ, Moodie J, Thomas BS, Smith FB. The environmental impact of coke-oven discharge. Experimental and theoretical approaches. 1st international Coke-making Congress, Essen, Sept 13-18, 1987, Paper H4.

13 Bhopal RS. The impact of industry on the health of surrounding communities: an analysis of epidemiological
and public health challenges. In: Hedley AJ, et al. Proceedings. The role of the ASAIHL in combating health ceedings. The role of the ASAIHL in combating health hazards of environmental pollution.

14 Lloyd DW, Barclay R, Lloyd MM. Lung cancer and other health problems in a Scottish industrial town. Ambio 1985;14:322-8.

15 Elliot $\mathrm{P}$, Hills $\mathrm{M}$, Beresford J, et al. Incidence of cancers of the larynx and lung near incinerators of waste solvents and oils in Great Britain. Lancet 1992;339:854-8.

16 Symington $\mathrm{P}$, Coggon D, Holgate $\mathrm{S}$. Respiratory symptoms in children at schools near a foundry. $\mathrm{Br} \mathcal{F}$ Indust Med 1992;48:588-91.

17 Dales R, Spitzer W, Suissa S, et al. Respiratory health of a population living downwind from natural gas refineries. Am Rev Respir Dis 1989;139:595-600.

18 Ware JH, Ferris G, Dockery DW, Spengler JD, Stram DO Speiger FE. Effects of ambient sulfur oxides and susSpeiger FE. Effects of ambient sulfur oxides and suspended particles on respiratory health of pre
children. Am Rev Respir Dis 1986;133:834-42.

19 Dockery DW, Speizer FE, Stram DO, et al. Effects of inhalable particulates on respiratory health of children. Am Rev Respir Dis 1989;139:587-94.

20 Viegi G, Pasletti P, Carrojji L, et al. Prevalence rates of respiratory symptoms in Italian general population samples exposed to different levels of air pollution Environ Health Perspect 1991;94:95-9.

21 Kardaun JWPF, Van der Maas PJ, Habbema JDF, Leentvaar-Kuijpers A, Rijcken B. Incidence of diseases of the lower respiratory tract in family practice and low level air pollution. Fam Pract 1989;6:86-91.

22 Pope AC, Schwartz J, Ransom HR. Daily mortality and $\mathrm{PM}^{10}$ pollution in Utah Valley. Arch Environ Health PM $^{10}$ pollution
1992;47:211-17.

23 Mackenbach JP, Looman CWN, Kurst AE. Air pollution, lagged effects of temperature, and mortality. The Netherlands 1979-1987. F Epidemiol Community Health 1993;47:121-126.

24 Advisory Group on Medical Aspects of Air Pollution Episodes. $\mathrm{SO}_{2}$ acid aerosols and particulates. London: HMSO, 1992.

25 Anonymous. Environmental pollution: it kills trees, but does it kill people? Lancet 1992;340:821-2.

26 Brown P. Popular epidemiology and toxic waste contamination: lay and professional ways of knowing. 7 Health Soc Behav 1992;33:267-81.

27 Paigen B. Controversy at Love Canal. Hastings Cent Rep 1982;12:29-37. 